\title{
Maternal and neonatal outcomes in teenage pregnancy: an observational study from Odisha
}

\author{
Arabinda Nepak, Surendra Nath Soren, Ashish Kumar Karjee*
}

Department of Obstetrics and Gynaecology, MKCG Medical College and Hospital, Odisha, India

Received: 16 January 2021

Accepted: 01 February 2021

\section{*Correspondence:}

Dr. Ashish Kumar Karjee,

E-mail: dr.ashishkarjee@gmail.com

Copyright: (c) the author(s), publisher and licensee Medip Academy. This is an open-access article distributed under the terms of the Creative Commons Attribution Non-Commercial License, which permits unrestricted non-commercial use, distribution, and reproduction in any medium, provided the original work is properly cited.

\begin{abstract}
Background: With changing socio-demographic landscape of India, teenage pregnancy has become an important public health issue. The present study was conducted to assess the incidence of teenage pregnancy in Berhampur, Odisha and various maternal and neonatal outcomes of these pregnancies.

Methods: This observational study was conducted on 564 antenatal mothers aged 16 to 19 years, who from October 2018 to September 2020. Demographic information of the mothers was noted. Maternal complications during antenatal, intrapartum and postpartum period were noted. Neonatal outcomes, mode of delivery, complications and need for intensive care unit admission was noted. The data collected was described in tabulated form.

Results: The incidence of teenage pregnancy at our centre was 4\%. Of the 564 teenage pregnancies, 214 were anaemic, pregnancy induced hypertension in 74 and 129 had preterm labour. The caesarean section rate was performed in $51.9 \%$, and the most common indications for caesarean section were fetal distress and cephalopelvic disproportion. Of the 553 live births, $1.04 \%$ of them weighed $<1.5 \mathrm{~kg}, 29.16 \%$ weighed $1.5 \mathrm{till} 2.5 \mathrm{~kg}$, $65.5 \%$ weighed between 2.5 to $3.5 \mathrm{~kg}$ and $5.2 \%$ weighed $>3.5 \mathrm{~kg}$. NICU admission was required for $26.9 \%$ of the neonates and the most common complication was neonatal jaundice, which was observed in $14.3 \%$.

Conclusions: Teenage pregnancies represent a high-risk. The present study demonstrated the various maternal as well as neonatal complications in teenage pregnancies. Those who experience teenage pregnancy should be given extra attention and care.
\end{abstract}

Keywords: Teenage pregnancy, Maternal and fetal outcome, Neonatal intensive care unit

\section{INTRODUCTION}

Adolescence is the transition period from childhood to adulthood. It is defined by the World Health Organization as period between 10 and 19 years of age. ${ }^{1}$ This age represents an important stage for ensuring a successful transition to adulthood. Recently, with changing sociodemographic landscape of India, teenage pregnancy has become an important public health issue. This issue is not unique to developing countries as even developed countries are dealing with this situation. Recent data estimates that about 60 million women were married before the age of 18 years and approximately 16 million women aged 15-19 years old give birth to a child. India being a young nation, has the highest proportion of adolescents. Therefore, teenage pregnancies are going to be an important issue in years to come.

Studies conducted in Taiwan, USA, and Korea showed that teenagers were $1.58,1.36$, and 1.16 times more likely to have preterm delivery than the adults, respectively. ${ }^{2}$ Studies conducted in Taiwan, USA, and Korea showed that teenagers were $1.58,1.36$, and 1.16 times more likely to have preterm delivery than the adults, respectively. ${ }^{3}$ Numerous social determinants causing teenage pregnancy include lack of education in general and on sex education, 
which result in poor health seeking behaviour and thus very abysmal utilization of health services like contraceptives, and abortion services. ${ }^{4}$ Therefore, the incidence and outcomes of teenage pregnancies can vary with the geographical location. The present study was conducted to assess the incidence of teenage pregnancy in Berhampur, Odisha and various maternal and neonatal outcomes of these pregnancies.

\section{METHODS}

This observational study was conducted on 564 antenatal mothers between the age of 16 to 19 years, who delivered at the department of obstetrics and gynaecology, from October 2018 to September 2020 at M.K.C.G. medical college, Berhampur, Odisha. We included cases aged 16 to 19 years, booked as well as un-booked pregnancies that crossed the period of viability (i.e., 28 weeks). All cases above the age of 19 years and those with a miscarriage were excluded from the final analysis. All included in the study were explained the purpose of the study. Those aged 18 years and above were included after obtaining written consent, while for those aged less than 18 years, written assent was obtained. The study was approved by the institutional ethics committee.

\section{Data collection and data analysis}

Using a pre-designed semi-structured questionnaire, demographic information regarding age, educational status, occupation, marital status, age at marriage, knowledge about pregnancy and delivery, antenatal visits were obtained from medical records. All cases underwent general examination, per abdomen examination, per vaginal examination and underwent routine haematological, microbiological and biochemical investigations. Routine ultrasonography and repeat ultrasonography were done for booked cases to rule out congenital anomalies, placental maturity, amniotic fluid index, biophysical profile and complications if any. Maternal complications during antenatal, intrapartum and postpartum period were noted. They were followed until delivery to know the mode of delivery, birth weight of the fetus and neonatal outcome was also noted. Once the patient set into labour, the cases were reviewed with the help of non-stress test and pelvic assessment was done. The course of labour was monitored according to WHO partograph. The neonatologist assessed each baby soon after the delivery. APGAR scores were recorded at one minute and five minutes. After delivery of the baby, active management of third stage of labour was done with injection oxytocin $10 \mathrm{U}$ intra muscular route for effective uterine contraction and retraction and controlled cord traction for the delivery of placenta.

The data were compiled in Microsoft excel and analysed in Epi info software (CDC, Atlanta). The data were described as means and standard deviation for quantitative variables and as frequency and proportions for qualitative variables.

\section{RESULTS}

Of the total 14100 pregnancies at our institution during the study period, 564 were teen pregnancies, (incidence $4 \%$ ). Table 1 describes the baseline characteristics of the study participants. It was observed that mean age was 18.7 years, $81.2 \%$ were primigravida $79 \%$ belonged to low socioeconomic status, $67.2 \%$ were from rural area and $97.7 \%$ were married. The various maternal complications are as described in Table 2. There were 214 anaemic mothers, $58 \%$ had mild anaemia, $40 \%$ had moderate and $2 \%$ had severe anaemia (Table 3 ). Pregnancy induced hypertension (PIH) was diagnosed in 74 cases, of which $40.5 \%$ had mild PIH, $37.83 \%$ had severe PIH and $21.63 \%$ had eclampsia. Of the 129 cases who had preterm labour, $79.06 \%$ had late preterm but had good neonatal outcome and 16 cases had very preterm delivery. The caesarean section rate was performed in $51.9 \%, 38.12 \%$ had normal vaginal delivery, 45 of them needed instrumental delivery and 11 had assisted breech delivery. The most common indications for caesarean section were fetal distress $(36.2 \%)$ and cephalopelvic disproportion (24.6\%). Of the 271 vaginal deliveries, 83 delivered within 6 hrs of duration, 181 of them delivered within 6-10 hrs and 7 of them took more than $10 \mathrm{hrs}$.

Table 1: Baseline characteristics of the study participants.

\begin{tabular}{|lll|}
\hline Variables & Number & Percentage (\%) \\
\hline Age (years) & & \\
\hline 17 & 22 & 4 \\
\hline 18 & 113 & 20 \\
\hline 19 & 429 & 76 \\
\hline Parity & & \\
\hline Primipara & 458 & 81.20 \\
\hline Multipara & 106 & 18.80 \\
\hline Registration status & & \\
\hline Un-booked & 360 & 63.85 \\
\hline Booked & 204 & 36.17 \\
\hline Socioeconomic status & & \\
\hline Low & 445 & 79 \\
\hline Middle & 119 & 21 \\
\hline High & 0 & 0 \\
\hline Education status & & \\
\hline Illiterate & 112 & 20 \\
\hline Primary education & 305 & 54 \\
\hline High school & 119 & 21 \\
\hline College & 28 & 5 \\
\hline Residence & & \\
\hline Rural & 379 & 67.20 \\
\hline Urban & 185 & 32.80 \\
\hline Marital status & & \\
\hline Married & 551 & 97.70 \\
\hline Unmarried & 13 & 2.30 \\
\hline
\end{tabular}

Of the 575 cases, 553 were live births, of which 11 died in the perinatal period, 16 were intrauterine death, 6 babies were still born and there were no congenital 
anomalies in any babies (Table 4). Of the 553 live births, $1.04 \%$ of them weighed $<1.5 \mathrm{~kg}, 29.16 \%$ weighed 1.5 till $2.5 \mathrm{~kg}, 65.5 \%$ weighed between 2.5 to $3.5 \mathrm{~kg}$ and $5.2 \%$ weighed $>3.5 \mathrm{~kg}$. NICU admission was required for $26.9 \%$ of the neonates and the most common complication was neonatal jaundice, which was observed in $14.3 \%$.

Table 2: Maternal complications.

\begin{tabular}{|lll|}
\hline Maternal complications & Number & $\%$ \\
\hline Anaemia & 214 & 38 \\
\hline Preterm labour & 129 & 23 \\
\hline Fetal distress & 124 & 22 \\
\hline Cephalopelvic disproportion & 84 & 15 \\
\hline $\begin{array}{l}\text { Pregnancy induced } \\
\text { hypertension }\end{array}$ & 74 & 13 \\
\hline Oligohydramnios & 73 & 13 \\
\hline PROM & 73 & 13 \\
\hline Post-dated pregnancy & 40 & 7 \\
\hline Malpresentation & 22 & 4 \\
\hline $\begin{array}{l}\text { Intrauterine growth } \\
\text { retardation }\end{array}$ & 16 & 3 \\
\hline Intrauterine fetal death & 16 & 3 \\
\hline Antepartum hemorrhage & 11 & 2 \\
\hline Postpartum hemorrhage & 11 & 2 \\
\hline Multiple gestation & 11 & 2 \\
\hline Still birth & 6 & 1 \\
\hline
\end{tabular}

Table 3: Maternal outcomes in our study population.

\begin{tabular}{|c|c|c|}
\hline Variables & Number & $\%$ \\
\hline \multicolumn{3}{|c|}{ Anaemia (n=214, Hb in $g / d l)$} \\
\hline Mild (10-10.9) & 124 & 58 \\
\hline Moderate (9.9-7) & 86 & 40 \\
\hline Severe $(6.9-4)$ & 4 & 2 \\
\hline Very severe $(<4)$ & 0 & 0 \\
\hline \multicolumn{3}{|c|}{ Pregnancy induced hypertension $(n=74)$} \\
\hline Mild & 30 & 40.54 \\
\hline Severe & 28 & 37.83 \\
\hline Eclampsia & 16 & 21.63 \\
\hline \multicolumn{3}{|l|}{ Preterm labor $(n=129)$} \\
\hline $\begin{array}{l}\text { Extremely preterm }(<28 \\
\text { weeks })\end{array}$ & 0 & 0 \\
\hline Very preterm & 16 & 12.40 \\
\hline Early preterm & 11 & 8.53 \\
\hline Late preterm & 102 & 79.06 \\
\hline \multicolumn{3}{|l|}{ Mode of delivery $(n=564)$} \\
\hline Caesarean section & 293 & 51.95 \\
\hline Normal vaginal delivery & 215 & 38.12 \\
\hline Forceps delivery & 23 & 4.08 \\
\hline Ventouse delivery & 22 & 3.90 \\
\hline Assisted breech & 11 & 1.95 \\
\hline \multicolumn{3}{|c|}{ Duration of labor ( $n=271$ ) (hours) } \\
\hline$<6$ & 83 & 30.80 \\
\hline $6-10$ & 181 & 66.66 \\
\hline$>10$ & 7 & 2.54 \\
\hline
\end{tabular}

Table 4: Neonatal outcomes in the present study.

\begin{tabular}{|c|c|c|}
\hline Variables & Number & $\%$ \\
\hline \multicolumn{3}{|l|}{ Fetal outcome $(n=575)$} \\
\hline Total live births & 542 & 94.20 \\
\hline Still born & 6 & 1 \\
\hline Perinatal death & 11 & 2 \\
\hline IUFD & 16 & 2.80 \\
\hline Congenital anomalies & 0 & 0 \\
\hline \multicolumn{3}{|l|}{ Birth weight $(\mathrm{n}=553)(\mathrm{kg})$} \\
\hline$<1.5$ & 6 & 1.04 \\
\hline $1.5-2.5$ & 161 & 29.16 \\
\hline $2.6-3.5$ & 357 & 64.58 \\
\hline$>3.5$ & 29 & 5.20 \\
\hline \multicolumn{3}{|l|}{ NICU admission $(n=553)$} \\
\hline Yes & 149 & 26.95 \\
\hline No & 404 & 73.05 \\
\hline \multicolumn{3}{|c|}{ Neonatal complications $(n=553)$} \\
\hline Neonatal jaundice & 79 & 14.30 \\
\hline Early onset sepsis & 35 & 6.30 \\
\hline $\begin{array}{l}\text { Respiratory illness - } \\
\text { TTNB/HMD/MAS }\end{array}$ & 30 & 5.40 \\
\hline Necrotizing enterocolitis & 10 & 1.80 \\
\hline $\begin{array}{l}\text { Hypoxic ischemic } \\
\text { encephalopathy }\end{array}$ & 8 & 1.40 \\
\hline Neonatal seizures & 7 & 1.20 \\
\hline
\end{tabular}

\section{DISCUSSION}

Teenage pregnancy remains major public and social health issue in India due to prevailing social preferences, old traditions and poor access to health care in remote rural areas. Lack of education deprives teenagers of the knowledge about family planning, leading to early pregnancy. We observed the incidence of teenage pregnancy to be $4 \%$ at our hospital. Majority of the study participants of our study were from low socioeconomic strata $(79 \%$ belonged to low socioeconomic status and $67.2 \%$ were from rural area). Devi et al reported the incidence of teenage pregnancy to be $5.56 \% .^{5}$ Rita et al reported the incidence to be $10.06 \% .^{6}$ Okram et al reported the incidence to be $7 \% .^{7}$ The national family health survey 4 , reported the incidence of teenage pregnancy to be $13.8 \%$ in rural areas and $6.6 \%$ in urban areas. ${ }^{8}$ It is possible to further reduce this incidence by reducing the trend of child marriage, improvement in female education, overall socioeconomic status of the family, improved health services and easier access to them, comprehensive antenatal care, institutional deliveries and postnatal care.

We observed $38 \%$ of the study participants to be anemic. Comparing with adult pregnancies, Devi et al found a higher prevalence of anemia among those with teenage pregnancies $(47 \%)$. inadequate nutritionist occurs due to poor eating habits which is common in adolescents. Okram and colleagues also found anemia to be the most common complication. Generally, the cause of anaemia is not the young age of the adolescent mother. It is often 
caused by the nutritional deficiencies, especially iron and folic acid, and in low-income countries by malaria and hookworm infection. In a study by Mahavarkar et al anaemia was also the most common complication seen. ${ }^{9}$ Severe anaemia leads to preterm labour, low birthweight, and related complications, postpartum hemorrhage and sepsis, in addition to impaired physical and cognitive development, and increased risk of morbidity in children and reduced work productivity in adults.

Many studies from many countries, comparing the risk of preterm in teenage verses adult pregnant women. Most of the studies found more preterm births in adolescents and made it clear that maternal age is an important independent factor. Preterm labor was observed in $23 \%$ of the study participants. Okram et al reported the rate of preterm to be $8 \%$, which was similar to that of Althabe et al. ${ }^{10}$ Caesarean section rate was found to be $51.9 \%$ in our study. The most common indication for Caesarean section was fetal distress $(36.2 \%)$ followed by cephalopelvic disproportion (24.6\%). Similar observations were made by Rita and colleagues as well. Other indications for caesarean delivery in their study were pre-eclampsia and related complications $(12 \%)$, fetal distress $(9.4 \%)$, malpresentations and placental causes $(3.7 \%)$ in our study. Okram and colleagues reported $31 \%$ caesarean rate

In our study, $30 \%$ of the babies born to teenagers had low birth weight. The incidence of IUGR was $3 \%$ in the present study and NICU admission was required in $27 \%$ of the babies born. Rita D et al reported the incidence of low birth weight in $12 \%$, NICU admission rate to be $8.4 \%$, and perinatal mortality to be $2 \%$. Thobbi et al reported the incidence of low birth weight to be $27.3 \%$ and it was the most common cause of perinatal mortality in teenage mothers in their study, which could be either due to prematurity or small for gestational age babies.

There are a few limitations of the study. Ours was a single centre study. As teenage pregnancy has numerous social determinants involved, the results of the present study may not be generalizable to other parts of India. Secondly, we did not compare the outcomes in teenager pregnancy with those of adult pregnancy, which limits our ability to comment on whether some adverse outcomes were associated with teenager pregnancy.

\section{CONCLUSION}

Teenage pregnancies represent a high-risk. The present study demonstrated the various maternal as well as neonatal complications in teenage pregnancies. This being a social issue, promotive and preventive measures at community level are required to help avoid teenage pregnancies. Those who experience teenage pregnancy should be given extra attention and care. Many of these complications are manageable, provided the access to services is available.

\section{Funding: No funding sources}

Conflict of interest: None declared

Ethical approval: The study was approved by the Institutional Ethics Committee

\section{REFERENCES}

1. Park K. Park's Textbook of Preventive and Social Medicine. 21st ed. Jabalpur, India: Banarasidas Bhanot. 2011;489-97.

2. Huang CC, Lin YC, Huang YT, Huang KH. Comparison of medical issues in antenatal and perinatal periods in early youth, adolescent, and young adult mothers in Taiwan: a 10-year nationwide study. BMC pregnancy and childbirth. 2014;14(1):260.

3. Lee SH, Lee SM, Lim NG, Kim HJ, Bae SH, Ock M et al. Differences in pregnancy outcomes, prenatal care utilization, and maternal complications between teenagers and adult women in Korea: a nationwide epidemiological study. Medicine. 2016;95(34).

4. Abebe AM, Fitie GW, Jember DA, Reda MM, Wake GE. Teenage Pregnancy and Its Adverse Obstetric and Perinatal Outcomes at Lemlem Karl Hospital, Tigray, Ethiopia, 2018. Bio Med Res Int. 2020;2020.

5. Devi G, Kayalvizhi, Poovathi M. Study of fetomaternal outcome of teenage pregnancy in a tertiary care hospital-MGMGH. Int $\mathrm{J}$ Reprod Contracept Obstet Gynecol. 2019;8:303-7.

6. Rita D, Naik K, Desai RM, Tungal S. Study of feto maternal outcome of teenage pregnancy at tertiary care hospital. Int $\mathrm{J}$ Reprod Contracept Obstet Gynecol. 2017;6:2841-5.

7. Okram SD, Reddy KM, Samyukta BSCN, Sadvika P, Betha K. Prevalence of teenage pregnancy and pregnancy outcome at a rural teaching hospital in India. Int J Reprod Contracept Obstet Gynecol. 2019;8:613-6.

8. National Family Health Survey:4, Available from: http://rchiips.org/nfhs/pdf/NFHS4/India.pdf. Accessed January 18, 2021.

9. Mahavarkar SH, Madhu CK, Mule VD. A comparative study of teenage pregnancy. Am J Obstet Gynecol. 2008;28(6):604-7.

10. Althabe F, Moore JL, Gibbons L, Berrueta M, Goudar SS, Chomba E et al. Adverse maternal and perinatal outcomes in adolescent pregnancies: The Global Network's Maternal Newborn Health Registry study. Reproduct Health. 2015;12(2):S8.

Cite this article as: Nepak A, Soren SN, Karjee AK. Maternal and neonatal outcomes in teenage pregnancy: an observational study from Odisha. Int J Reprod Contracept Obstet Gynecol 2021;10:889-92. 